\title{
Blood plasma clinical-chemical parameters as biomarker endpoints for organohalogen contaminant exposure in Norwegian raptor nestlings
}

Sonne, Christian; Bustnes, Jan O.; Herzke, Dorte; Jaspers, Veerle L. B.; Covaci, Adrian ; Eulaers, Igor; Halley, Duncan J.; Moum, Truls; Ballesteros, Manuel; Eens, Marcel; Ims, Rolf A.; Hanssen, Sveinn A.; Erikstad, Kjell E.; Johnsen, Trond V.; Riget, Frank Farsø; Jensen, Asger Lundorff; Kjelgaard-Hansen, Mads

Published in:

Ecotoxicology and Environmental Safety

DOI:

10.1016/j.ecoenv.2012.02.012

Publication date:

2012

Document version

Early version, also known as pre-print

Citation for published version (APA):

Sonne, C., Bustnes, J. O., Herzke, D., Jaspers, V. L. B., Covaci, A., Eulaers, I., Halley, D. J., Moum, T., Ballesteros, M., Eens, M., Ims, R. A., Hanssen, S. A., Erikstad, K. E., Johnsen, T. V., Riget, F. F., Jensen, A. L., \& Kjelgaard-Hansen, M. (2012). Blood plasma clinical-chemical parameters as biomarker endpoints for organohalogen contaminant exposure in Norwegian raptor nestlings. Ecotoxicology and Environmental Safety, 80, 76-83. https://doi.org/10.1016/j.ecoenv.2012.02.012 


\title{
Blood plasma clinical-chemical parameters as biomarker endpoints for organohalogen contaminant exposure in Norwegian raptor nestlings
}

\author{
Christian Sonne ${ }^{a, *}$, Jan O. Bustnes ${ }^{b}$, Dorte Herzke ${ }^{c}$, Veerle L.B. Jaspers ${ }^{d}$, Adrian Covaci ${ }^{d}$, Igor Eulaers ${ }^{d}$, \\ Duncan J. Halley ${ }^{\mathrm{e}}$, Truls Moum ${ }^{\mathrm{f}}$, Manuel Ballesteros ${ }^{\mathrm{b}}$, Marcel Eens ${ }^{\mathrm{d}}$, Rolf A. Ims ${ }^{\mathrm{b}}$, Sveinn A. Hanssen ${ }^{\mathrm{b}}$, \\ Kjell E. Erikstad $^{\text {b}}$, Trond V. Johnsen ${ }^{\text {b }}$, Frank F. Rigét ${ }^{\mathrm{a}}$, Asger L. Jensen ${ }^{\mathrm{g}}$, Mads Kjelgaard-Hansen ${ }^{\mathrm{h}}$ \\ ${ }^{a}$ Department of Bioscience, Faculty of Science and Technology, Aarhus University, Frederiksborgvej 399, PO Box 358, DK-4000 Roskilde, Denmark \\ ${ }^{\mathrm{b}}$ Unit for Arctic Ecology, FRAM-High North Research Centre for Climate and the Environment (Fram Centre), Norwegian Institute for Nature Research, \\ Hjalmar Johansensgt. 14, NO-9296 Tromsø, Norway \\ c FRAM-High North Research Centre for Climate and the Environment (Fram Centre), Norwegian Institute for Air Research, Hjalmar Johansensgt. 14, \\ NO-9296 Tromsø, Norway \\ ${ }^{\mathrm{d}}$ Ethology Research Group and Toxicological Centre, University of Antwerp, Universiteitsplein 1, BE-2610 Antwerp, Belgium \\ e Unit for Terrestrial Ecology, Norwegian Institute for Nature Research, Tungasletta 2, NO-7485 Trondheim, Norway \\ ${ }^{\mathrm{f}}$ Faculty of Biosciences and Aquaculture, University of Nordland, NO-8049 Bodø, Norway \\ ${ }^{\mathrm{g}}$ Department of Basic Animal and Veterinary Sciences, Faculty of Life Sciences, University of Copenhagen, Frederiksberg, Denmark \\ hepartment of Small Animal Clinical Sciences, Faculty of Life Sciences, University of Copenhagen, Frederiksberg, Denmark
}

\section{A R T I C L E I N F O}

Article history:

Received 13 December 2011

Received in revised form

9 February 2012

Accepted 12 February 2012

Available online 24 March 2012

Keywords:

Birds of prey

Blood clinical-chemical parameters

Nestling

Norway

Perfluorinated compounds

Persistent organic pollutants

\section{A B S T R A C T}

Raptors are exposed to biomagnifying and toxic organohalogenated compounds (OHCs) such as organochlorines, brominated flame retardants and perfluorinated compounds. To investigate how $\mathrm{OHC}$ exposure may affect biochemical pathways we collected blood plasma from Norwegian northern goshawk $(n=56)$, golden eagle $(n=12)$ and white-tailed eagle $(n=36)$ nestlings during three consecutive breeding seasons. We found that blood plasma concentrations of calcium, sodium, creatinine, cholesterol, albumin, total protein, urea, inorganic phosphate, protein:creatinine, urea:creatinine and uric acid:creatinine ratios and liver enzymes ALKP and ALAT were positively correlated to PCBs, chlordanes, $p, p^{\prime}$-DDE, HCB, PFCs and/or PBDEs. Total bilirubin and glucose were negatively correlated to $\mathrm{PCBs}$ while magnesium and potassium were negatively correlated to $\mathrm{HCB}$ and $p, p^{\prime}$-DDE. In addition, protein:creatinine and ALAT were also negatively correlated to PCBs and PFCs, respectively. The most significant relationships were found for the highly contaminated northern goshawks and white-tailed eagles. The statistical relationships between OHCs and BCCPs indicate that biochemical pathways could be influenced while it is uncertain if such changes have any health effects. The $\mathrm{OHC}$ concentrations were below concentrations causing reproductive toxicity in adults of other raptor species but similar to those of concern for endocrine disruption of thyroid hormones in e.g., bald eagles.

(c) 2012 Elsevier Inc. All rights reserved.

\section{Introduction}

Xenobiotic pollutants, such as organohalogenated compounds (OHCs) are environmental stressors suspected to have various health impacts, including neuro-endocrine/immune disruption and organ toxicity (AMAP 1998, 2004; Chrousos and Gold,
1992; Johnson et al., 1992; Letcher et al., 2010; Sharit and Salvendy, 1982; Sonne, 2010). It has been shown that OHCs have a potential toxic impact on liver and kidney function in wild bird species as well as in humans and laboratory mammals (de le Court et al., 1995; Dieter et al., 1976, 1977; Fischbein, 1985; Hayes et al., 1984; Kutlu et al., 2007; van Wyk et al., 1998).

\footnotetext{
* Correspondence to: Senior Research Scientist, DVM, PhD, Wildlife Veterinarian and Toxicologist, Institute of Bioscience, Faculty of Science and Technology, Aarhus University, Frederiksborgvej 399, PO Box 358, DK-4000 Roskilde, Denmark. Fax: +45 46301914.

E-mail addresses: csh@dmu.dk (C. Sonne), jan.o.bustnes@nina.no (J.O. Bustnes), dorte.herzke@nilu.no (D. Herzke), veerle.jaspers@ua.ac.be (V.L.B. Jaspers), adrian.covaci@ua.ac.be (A. Covaci), igor.eulaers@ua.ac.be (I. Eulaers), duncan.halley@nina.no (D.J. Halley), Truls.Moum@uin.no (T. Moum),

Manuel.Ballesteros@nina.no (M. Ballesteros), marcel.eens@ua.ac.be (M. Eens), rolf.ims@ib.uit.no (R.A. Ims), sveinn.a.hanssen@nina.no (S.A. Hanssen),

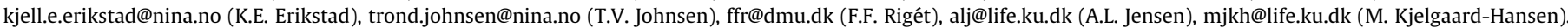

URL: http://www.neri.dk (C. Sonne).
} 
Blood clinical-chemical parameters (BCCPs) can be useful as biomarker endpoints for OHC exposure, but are still rarely analysed for in wildlife studies. BCCPs reflect e.g., health and homeostasis of liver (alkaline phosphatase; alanine aminotransferase; bile acid; total bilirubin; albumin; total protein and cholesterol) while other reflect kidney function (urea, protein, uric acid; creatinine; uric acid:creatinine; protein:creatinine) and bone metabolism (alkaline phosphatase; total protein; protein:creatinine, inorganic phosphate and calcium) (de le Court et al., 1995; Thrall et al., 2006; van Wyk et al., 1998). In addition, the energy metabolism is reflected by the total concentrations of proteins, uric acid, glucose, fructosamine and creatinine, and digestion and pancreatic diseases can be evaluated by amylase levels. Furthermore, magnesium, potassium, sodium, urea, uric acid and proteins are important parameters to reflect electrolytic homeostasis and dehydration (Thrall et al., 2006). In conclusion, pollution studies may benefit from the inclusion of such biomarkers in order to shed light on potential health effects.

In northern Norway, several marine bird and fish species have considerable loads of OHCs, which biomagnify in white-tailed eagles (Haliaeetus albicilla) preying upon marine organisms (Bustnes et al., 2008; Eulaers et al., 2011; Gjershaug et al., 2008; Helberg et al., 2005; Julshamn et al., 2004). Terrestrial prey species are relatively less exposed to OHCs than those from the marine environment. Therefore, raptors, such as golden eagles (Aquila chrysaetos) and northern goshawks (Accipiter gentilis), that have specialised on terrestrial food webs are likely to be less exposed to OHCs than marine predatory species (AMAP, 1998, 2004; Gjershaug et al., 2008; Herzke et al., 2002, 2005; Letcher et al., 2010; Sonne, 2010; Sonne et al., 2010).

A pilot study on OHCs and BCCPs was conducted on golden eagle, white-tailed eagle and northern goshawk nestlings in 2008 (Sonne et al., 2010). We suggested that (some) OHCs may impact organ-systems and homeostasis in northern Norway raptor nestlings. In the present paper we extend our investigation of these potential impacts of $\mathrm{OHC}$ exposure based on extensive sampling and analysis of BCCPs in nestlings of white-tailed eagles, golden eagles and northern goshawks from Troms and Finnmark counties of northern Norway. The study species and nest locations were chosen in order to have breeding pairs and nestlings that were supposedly high (white-tailed eagles breeding in the coastal environment) and low (northern goshawks and golden eagles in the terrestrial environment) in their OHC body burdens due to their reliance on the respective food webs in their habitat. Thus, we present an extensive investigation in three raptor species of biochemical parameters previously used as biochemical health parameters for OHC-induced perturbations in organ-systems. Doing so, we investigate species-specific differences and yearto-year variations.

\section{Materials and methods}

\subsection{Study design and sampling}

The study was conducted on white-tailed eagles $(n=36)$ and northern goshawks $(n=56)$ from Troms Province, and golden eagles $(n=12)$ from Finnmark Province, northern Norway. The study area ranged from N $69^{\circ}$ to $71^{\circ}$ and from $\mathrm{E}$ $18^{\circ}$ to $26^{\circ}$ (Fig. 1). During year 2008, 2009 and 2010, nests of the three species were checked for breeding activity from late March to the middle of May using binoculars and telescopes, whilst keeping a distance to avoid disturbing the breeding pairs. The presence of at least one bird lying on the nest was used as a confirmation of breeding activity. A large number of nests of all three species were visited and birds with territorial behaviour were recorded. In late April and early May it was determined if the birds had laid eggs. In May - June nestlings in successful nests were inspected ca. 3 weeks after hatching. The nestlings were lowered from the nest in a nylon bag and brachial vein blood plasma $0.1-4.0 \mathrm{~mL}$ heparin-coated syringe) was sampled from a total of 51 different nests. After each sampling day, the blood was centrifuged at $8000 \mathrm{rpm}$ for $10 \mathrm{~min}, 1 \mathrm{~mL}$ supernatant plasma was transferred to a sterile $1.5 \mathrm{~mL}$ Eppendorf ${ }^{\mathbb{R}}$ tube and frozen at
$-20{ }^{\circ} \mathrm{C}$ until biochemical and contaminant analyses. The study was approved by the National Animal Research Authority of Norway.

\subsection{Analyses for BCCPs}

The 19 BCCP analyses were conducted at the Central Laboratory at the Department of Small Animal Clinical Sciences (University of Copenhagen, Denmark) and all samples were analysed within six months after sampling. The analyses included albumin (Alb; $\mathrm{g} \mathrm{L}^{-1}$ ), glucose $\left(\mathrm{Glu}\right.$; $\mathrm{mmol} \mathrm{L}^{-1}$ ), total protein (TP; $\mathrm{g} \mathrm{L}^{-1}$ ), alkaline phosphatase (ALKP; $\mathrm{U} \mathrm{L}^{-1}$ ), alanine aminotransferase (ALAT; $\mathrm{UL}^{-1}$ ), total bilirubin (TB; $\mu \mathrm{mol} \mathrm{L}^{-1}$ ), fructosamine (Fructo; $\mu \mathrm{mol} \mathrm{L}^{-1}$ ), cholesterol (Cho; mmol L ${ }^{-1}$ ), creatinine (Cre; $\mu \mathrm{mol} \mathrm{L}{ }^{-1}$ ), inorganic phosphate (Iph; mmol L ${ }^{-1}$ ), bile acids (BA; $\mu \mathrm{mol} \mathrm{L}^{-1}$ ), amylase (Amy; $\mathrm{UL}^{-1}$ ), urea (Urea; mmol L ${ }^{-1}$ ), gamma glutamyltransferase $\left(\mathrm{GGT}\right.$; $\left.\mathrm{U} \mathrm{L}^{-1}\right)$, calcium $\left(\mathrm{Ca} ; \mathrm{mmol} \mathrm{L}^{-1}\right)$, magnesium (Mg; mmol L $\left.{ }^{-1}\right)$, uric acid (UA; $\mathrm{U} \mathrm{L}^{-1}$ ), sodium $\left(\mathrm{Na} ; \mathrm{mmol} \mathrm{L}^{-1}\right.$ ) and potassium $\left(\mathrm{K} ; \mathrm{mmol} \mathrm{L}^{-1}\right)$. When interpreting BCCPs, they are best categorised into three liver enzymes and a liver function test compound (ALKP, ALAT, GGT and bile acid), one digestive enzyme (Amy), two protein groups (Alb; TP), two erythrocyte metabolism waste products (TB; BA), cholesterol, two carbohydrates (Glu; Fructo), one muscle break-down product (Cre), five electrolytes/minerals (Iph, Ca, Mg, $\mathrm{Na}, \mathrm{K}$ ) and two protein waste products (Urea; UA). In addition protein:creatinine, urea:creatinine and uric acid:creatinine ratios were introduced to represent creatinine clearance and reflect glomerular filtration rates (renal functioning). Further details on BCCP analysis and quality control can be found in Sonne et al. (2010).

\subsection{Determination of $\mathrm{OHCS}$}

Details on OHC determination can be found in Herzke et al. (2005), Götsch et al. (2004) and Sonne et al. (2010). Briefly, blood plasma samples from nestlings were analysed for a set of organochlorines (OCs), including polychlorinated biphenyls (PCBs: CB 18, 28, 99, 101, 105, 118, 138, 153, 180, 183, 187 and 194), $p, p^{\prime}$-DDE (dichlorodiphenyldichloroethylene), hexachlorobenzene (HCB), chlordanes (CHLs: t-chlordane, c-chlordane, oxy-chlordane, t-nonachlor, c-nonachlor), polybrominated diphenyl ethers (PBDEs: BDE 28, 47, 99, 100, 153 and 154) and perfluorinated compounds (PFCs: PFHpS, PFOS, PFDcS, PFPA, PFOA, PFNA, PFDcA, PFUnA, PFDoA, PFTriA). The compounds were categorised into $\sum$ PCBs, $p, p^{\prime}-\mathrm{DDE}$, $\mathrm{HCB}, \sum \mathrm{CHLs}$, $\sum$ PBDEs, $\sum$ PFCs and all concentrations are given in $\mathrm{ng} \mathrm{mL}^{-1} \mathrm{ww}$ (wet weight) (Table 2). Due to low plasma volumes from nestlings in 2009 and 2010 some values are missing and the sample size is reduced. In order to meet $\mathrm{QA} / \mathrm{QC}$ requirements, ${ }^{13} \mathrm{C}$-labelled internal standards were used. A blank sample and a standard reference material (NIST 1958, human serum) were analysed for each 10th sample. No blank contamination was detected with the applied methods. The recovery of the ${ }^{13} \mathrm{C}$-labelled OCs and PFCs varied between 50 and $110 \%$. The results of the analysed SRM fitted within 75 and $110 \%$. For the PFCs a fit of $85 \%$ was achieved.

\subsection{Statistical analyses}

The statistical analyses were performed R version 2.12.1 ( $\mathrm{R}$ Development Core Team, 2011). Initially, OHC data were log-transformed in order to meet the assumptions of equal variance and homogeneity. Then, all BCCP data sets were tested for normality and homogeneity (equal variance) by Shapiro-Wilk and

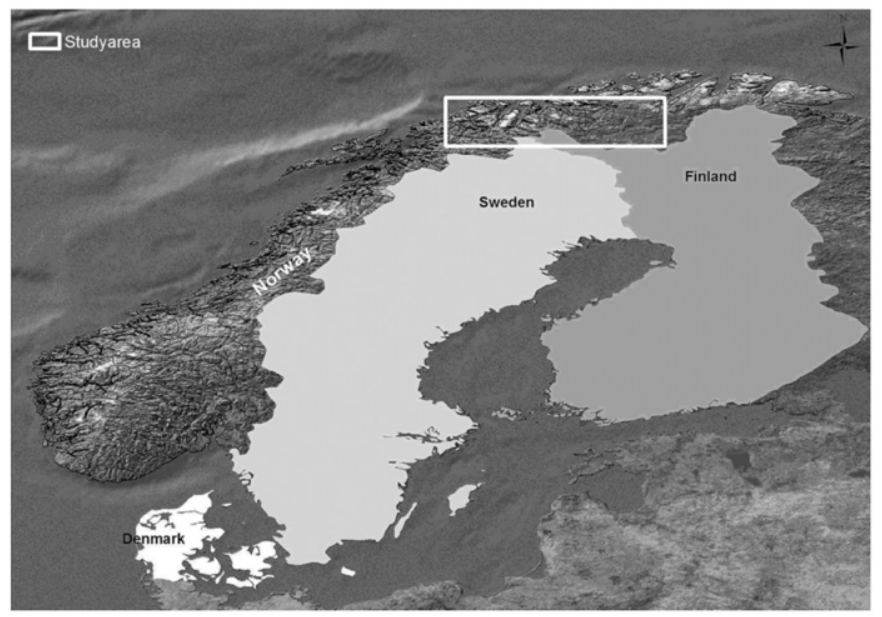

Fig. 1. Map identifying the study area in Troms and Finnmark Provinces of northern Norway. 
Table 1

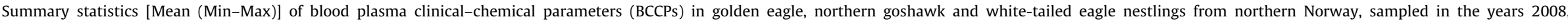
2009 and 2010.

\begin{tabular}{|c|c|c|c|c|c|c|c|c|c|}
\hline \multirow[t]{2}{*}{ BCCPs } & \multicolumn{3}{|l|}{ Golden eagle } & \multicolumn{3}{|l|}{ Northern goshawk } & \multicolumn{3}{|l|}{ White-tailed eagle } \\
\hline & $2008(n=2)$ & $2009(n=1)$ & $2010(n=9)$ & $2008(n=16)$ & $2009(n=24)$ & $2010(n=16)$ & $2008(n=5)$ & $2009(n=16)$ & $2010(n=15)$ \\
\hline Alkaline phosphatase $\left(\mathrm{UL}^{-1}\right)$ & $1331-1595$ & 877 & $962(600-1250)$ & $1381(740-1451)$ & $1195(816-1604)$ & $1431(1112-1919)$ & $1247(974-1632)$ & $1117(818-1560)$ & $1192(415-1921)$ \\
\hline Albumin $\left(\mathrm{g} \mathrm{L}^{-1}\right)$ & $13.9-14.5$ & 12.9 & $15.03(13.9-16.9)$ & $13(11.7-14)$ & $12.07(9.8-13.7)$ & $12.7(11.3-14.4)$ & $12.7(11-14.4)$ & $14(12.3-16-6)$ & $14.3(10.4-17.2)$ \\
\hline Protein:creatinine $\left(\mathrm{g} \mu \mathrm{mol}^{-1}\right)$ & $1.13-2.71$ & 2.65 & $3(1.46-5)$ & $2(1.13-2.71)$ & $2.1(1.36-3.78)$ & $3.11(2.02-4.21)$ & $2.3(1.07-2.44)$ & $2.52(1.1-4.79)$ & $2.97(1.38-5.32)$ \\
\hline Uric acid $\left(\mathrm{U} \mathrm{L}^{-1}\right)$ & $367-967$ & 475 & $842(478-1184)$ & $715(367-808)$ & $835(428-1304)$ & $927(358-1393)$ & $611(207-1200)$ & $730(291-1378)$ & $879(278-1298)$ \\
\hline Uric acid:creatinine $(\mathrm{U} \mu \mathrm{mc}$ & $33.3-33.4$ & 47.5 & $73.6(39.8-112)$ & $41(7.9-92)$ & $64.7(0-107)$ & $108(51.12-160)$ & $31(24-62)$ & $61.36(24.21-138)$ & $83.56(31.23-159)$ \\
\hline Urea:creatinine $10 \mathrm{E} 3$ & $0.10-0.15$ & 0.27 & $0.26(0.15-0.5)$ & $0.2(0.14-0.35)$ & $0.27(0.18-0.41)$ & $0.33(0.18-0.46)$ & $0.15(0.0-0.57)$ & $0.14(0.05-0.21)$ & $0.15(0.05-0.23)$ \\
\hline Cholesterol $\left(\mathrm{mmol} \mathrm{L}^{-1}\right)$ & $4.2-4.8$ & 4.56 & $5.5(4.5-7.5)$ & $4(3.15-5.78)$ & $4.17(3.43-4.85)$ & $4.21(3.38-5.77)$ & $6.11(6.01-9.18)$ & $6.24(4.89-7.78)$ & $6.48(5.26-9.47)$ \\
\hline Fructosamine $\left(\mu \mathrm{mol} \mathrm{L}^{-1}\right)$ & $174-184$ & 169 & $194(169-228)$ & $154(173-210)$ & $193(158-242)$ & $177(154-200)$ & $187(127-223)$ & $218(194-253)$ & $203(161-253)$ \\
\hline Creatinine $\left(\mu \mathrm{mol} \mathrm{L}^{-1}\right)$ & $11-29$ & 10 & $12.1(6-24)$ & $17(12-25)$ & $12.54(7-19)$ & $8.63(6-12)$ & $13(8-26)$ & $13.06(6-27)$ & $11.6(6-31)$ \\
\hline Total bilirubin $\left(\mu \mathrm{mol} \mathrm{L}^{-1}\right)$ & $8.3-17.1$ & 12 & $11.6(8.2-16)$ & $16(13.5-19.3)$ & $15.3(8-24.4)$ & $19.04(12.5-39.6)$ & $16(9.9-26)$ & $14.98(7.9-26.7)$ & $14.57(9.5-28.2)$ \\
\hline Alanine aminotransferase $\left(\mathrm{U} \mathrm{L}^{-1}\right)$ & $12-16$ & 8 & $13.56(10-18)$ & $18(14-27)$ & $19.67(7-30)$ & $18.9(7-26)$ & $15(14-27)$ & $18.1(15-22)$ & $20.5(16-27)$ \\
\hline Gamma glutamyltransferase $\left(\mathrm{UL}^{-1}\right)$ & $4-5$ & 5 & $4.3(4-5)$ & $5(2-8)$ & $6.1(2-10)$ & $5.9(4-9)$ & $4.82(2-8)$ & $3.9(2-5)$ & $2.5(1-6)$ \\
\hline Amylase $\left(\mathrm{UL}^{-1}\right)$ & 483-569 & 575 & $692(256-1537)$ & $772(365-813)$ & $868(614-1453)$ & $918(635-1183)$ & $493(416-1136)$ & $448(204-611)$ & $466(182-801)$ \\
\hline Total protein $\left(\mathrm{g} \mathrm{L}^{-1}\right)$ & $29.8-32.8$ & 26.5 & $31.2(27.8-36.2)$ & $27(25.5-31.2)$ & $24.6(21.7-28.8)$ & $25.9(22.5-29.2)$ & $27.6(23.3-29.4)$ & $28.9(25.1-40)$ & $30.2(22-42.6)$ \\
\hline Urea $\left(\mathrm{mmol} \mathrm{L}^{-1}\right)$ & $1.64-2.89$ & 2.66 & $2.87(1.78-4.64)$ & $3(1.08-11.9)$ & $3.31(1.99-5.03)$ & $2.28(1.36-3.68)$ & $2.2(2.15-4.41)$ & $1.63(0.66-2.34)$ & $1.6(0.85-2.5)$ \\
\hline Bile acids $\left(\mu \mathrm{mol} \mathrm{L}^{-1}\right)$ & $37.2-57.5$ & 16 & $20.6(2-53)$ & $55(43.7-75.8)$ & $644(25-1875)$ & $18.5(6-39)$ & $50(44.4-158)$ & $28.94(3-103)$ & $22.33(2-40)$ \\
\hline Glucose $\left(\mathrm{mmol} \mathrm{L}^{-1}\right)$ & $16.9-18.1$ & 17.03 & $13.2(6.6-17.6)$ & $17(14.3-17.4)$ & $16.85(15.18-18.91)$ & $16.93(14.93-18.53)$ & $15.8(15.5-20.7)$ & $15.68(14.32-18.25)$ & $14.25(11.93-15.97)$ \\
\hline Inorganic phosphate $\left(\mathrm{mmol} \mathrm{L}^{-1}\right)$ & $2.05-2.17$ & 1.92 & $2.79(1.18-5.09)$ & $2(1.77-2.21)$ & $1.75(1.11-2.68)$ & $1.81(1.24-2.39)$ & $2(1.5-2.44)$ & $1.9(1.48-2.32)$ & $2.07(1.48-3.17)$ \\
\hline Calcium $\left(\mathrm{mmol} \mathrm{L}^{-1}\right)$ & $2.33-2.47$ & 2.42 & $2.36(1.9-2.72)$ & $2(2.26-2.62)$ & $1.81(0.91-2.65)$ & $2.34(2.15-2.59)$ & $2.45(2.26-2.62)$ & $2.34(1.7-2.68)$ & $2.42(1.65-2.74)$ \\
\hline Magnesium $\left(\mathrm{mmol} \mathrm{L}^{-1}\right)$ & $0.87-0.89$ & 0.82 & $1.08(0.71-1.69)$ & $0.8(0.79-0.87)$ & $0.77(0.54-1.49)$ & $0.87(0.64-1.29)$ & $0.8(0.73-1.16)$ & $0.76(0.66-0.85)$ & $0.75(0.46-0.94)$ \\
\hline Sodium $\left(\mathrm{mmol} \mathrm{L}^{-1}\right)$ & $155-156$ & 155 & $157(154-160)$ & $153(149-155)$ & $155(146-160)$ & $158(154-168)$ & $152(150-156)$ & $150(146-152)$ & 151 (133-159) \\
\hline Potassium $\left(\mathrm{mmol} \mathrm{L}^{-1}\right)$ & $1.86-2.9$ & 3.27 & $4.24(1.76-7.97)$ & $2(2.23-4.95)$ & $2.05(0.85-5.17)$ & $2.28(1.01-3.97)$ & $2.9(0.75-3.03)$ & $2.71(2.08-3.56)$ & $2.8(2.05-3.93)$ \\
\hline
\end{tabular}


Table 2

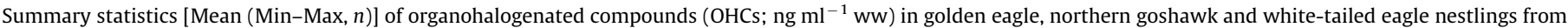
northern Norway, sampled in the years 2008, 2009 and 2010. The reason for missing ( - ) and reduced sample sizes ( $n$ ) were limited plasma volumes.

\begin{tabular}{|c|c|c|c|c|c|c|c|c|c|}
\hline \multirow[t]{2}{*}{ OHCs } & \multicolumn{3}{|l|}{ Golden eagles } & \multicolumn{3}{|l|}{ Northern goshawks } & \multicolumn{3}{|c|}{ White-tailed eagles } \\
\hline & 2008 & 2009 & 2010 & 2008 & 2009 & 2010 & 2008 & 2009 & 2010 \\
\hline$\sum \mathrm{PCB}$ & $3.8-14.91(2)$ & - & $23(5.1-6.1,9)$ & $8.4(2.3-45,16)$ & $13(0.28-32,23)$ & $13(.69-31,16)$ & $20(9.1-69,5)$ & $35(10-77,16)$ & $32(4.5-122,15)$ \\
\hline$p, p^{\prime}-\mathrm{DDE}$ & $0.60-4.9(2)$ & - & $8(0.9-18.2,9)$ & $7.52(1.8-25,16)$ & $3.4(0.85-11,23)$ & $4.8(1.8-10,16)$ & $5.2(1-11,5)$ & $11(2.2-26,15)$ & $8.8(1.2-41,15)$ \\
\hline $\mathrm{HCB}$ & $0.19-0.19(2)$ & - & $1.9(0.51-3.5,7)$ & $0.49(0.15-2.3,16)$ & $0.66(0.29-1.2,15)$ & $0.9(0.36-1.3,16)$ & $0.82(0.5-0.98,5)$ & $1.1(0.43-1.5,13)$ & $2.5(0.66-6.4,15)$ \\
\hline$\sum \mathrm{CHL}$ & $0.05-0.76(2)$ & - & $2.8(0.04-5.48,5)$ & $0.74(0.23-2.6,16)$ & $1.2(0-4.8,24)$ & $0.9(0.06-2.6,12)$ & $2.2(0.9-5.1,5)$ & $1.45(0.27-4.8,14)$ & $3.3(0.51-14,15)$ \\
\hline$\sum$ PBDE & $0.25-0.30(2)$ & - & $4.7(0-15,9)$ & $0.73(0.16-4.6,16)$ & - & $3.4(0-10,16)$ & $2(0.39-4.6,5)$ & - & $8.8(2.4-28,15)$ \\
\hline$\sum \mathrm{PFC}^{*}$ & $0.9-1.3(2)$ & - & $12(2.7-29,8)$ & $21(8.8-99,16)$ & $151(5.9-607,8)$ & $25(3.7-116,16)$ & $55(33-70,5)$ & $57(16-197,15)$ & $32(9.6-60,15)$ \\
\hline
\end{tabular}

* $p<0.05$ (white-tailed eagles $>$ golden eagles).

Bartlett tests, respectively, in order to determine for each BCCP the necessity of either parametric or non-parametric tests. In those cases where the BCCP data with or without log-transformation met the requirements for parametric testing, a linear mixed effect model was used. The model incorporated BCCPs as dependent variable and nest-year (siblings of same year) as explanatory random (nested) factor and species and year as explanatory fixed factors in order to account for autocorrelation due to the occurrence of siblings from the same nest. Due to the relatively low golden eagle sample size only white-tailed eagles and goshawks were included in the analyses testing effects from species and year. This was followed by Pearson's product-moment correlation to test for the relationship between $\mathrm{OHC}$ and BCCP concentrations using mean of nest-year (siblings of same year) for each species, separately.

In those cases where the data did not meet the requirements for parametric testing, the non-parametric Kruskall-Wallis test was applied to test for BCCP differences between species and years while Spearman's Rank correlations were applied to test for the relationship between OHC and BCCP concentrations using mean of nest-year (siblings of same year) for each species. In all correlation analyses the average values of siblings were used. None of the Pearson's productmoment analyses were Bonferroni corrected in order not to introduce type II errors (i.e., rejecting true null hypothesis) and as each specific OHCs vs. BCCPs was of clinical/biological interest rather than just the pattern (Perneger, 1998).

Principal component analysis (PCA) was applied to investigate the patterns of BCCPs in white-tailed eagle and goshawk nestlings. The PCA was performed on the correlation matrix and BCCPs were scaled to unit variance. The level of significance was set to $p=0.05$ while significant levels of $0.05 \leq p<0.10$ was considered a trend (Zar, 1984).

\section{Results and discussion}

\subsection{Species variation in $B C C P$ and $\mathrm{OHC}$ concentrations}

We found significant differences between white-tailed eagles and goshawks for all BCCP analysed with the exception of protein:creatinine ratios, uric acid, total bilirubin, creatinine, alanine aminotransferase, total protein and magnesium (Tables 1 and 2). White-tailed eagles had the highest blood plasma concentrations of albumin, cholesterol, fructosamine, calcium, inorganic phosphate and the elemental electrolyte potassium (all $p<0.05$; Table 3 ), while goshawks had the highest concentrations of gamma glutamyltransferase, alkaline phosphatase, amylase, uric acid:creatinine ratio, sodium and urea (protein metabolism waste product) as supported by the high urea:creatinine ratios. Such species differences are most often due to differences in physiology and dietary composition (Braun, 2003; Harr, 2002; Richards and Proszkowiec-Weglarz, 2007; Schulz et al., 2000; Van Loveren et al., 2001). High protein and cholesterol could indicate that white-tailed eagles are more dehydrated due to weather conditions and feeding behaviour and/or faster growing (Ettinger and Feldman, 1995; Ferrer and Dobado-Berrios, 1998; Gjershaug et al., 2008; Herzke et al., 2002, 2005; Thrall et al., 2006; Waikar and Bonventre, 2008).

Ten distinct OHC groups were measured in the blood plasma of all three raptor species (Table 2). The most dominating $\mathrm{OHC}$ groups were $\mathrm{PCBs}$ and $p, p^{\prime}$-DDE, and all OHC groups were
Table 3

Results from the analyses of effects from species (white-tailed eagle and northern goshawk) and year on BCCPs using parametric (linear mixed effect model; BCCPs $\sim$ species + year) and non-parametric (Kruskall-Wallis) tests. WTE: whitetailed eagle, NG: northern goshawk.

\begin{tabular}{|c|c|c|}
\hline BCCPs & Species & Year \\
\hline \multicolumn{3}{|l|}{ Linear mixed effect model } \\
\hline Alkaline phosphatase & WTE $<\mathrm{NG}^{*}$ & n.s. \\
\hline Albumin & $\mathrm{NG}<\mathrm{WTE}^{* * * *}$ & n.s. \\
\hline Uric acid & n.s. & $2008<2009<2010^{*}$ \\
\hline Uric acid:creatinine & WTE $<N G^{* * * *}$ & $2008<2009<2010^{\text {tr. }}$ \\
\hline Urea:creatinine & $\mathrm{WTE}<\mathrm{NG}^{* * * *}$ & $2008<2009<2010^{\text {tr. }}$ \\
\hline Total bilirubin & n.s. & n.s. \\
\hline Cholesterol & $\mathrm{NG}<\mathrm{WTE}^{* * * *}$ & n.s. \\
\hline Fructosamine & $\mathrm{NG}<\mathrm{WTE}^{* * * *}$ & $2008<2010<2009^{* * * *}$ \\
\hline Creatinine & n.s. & $2010<2009<2008^{* * * *}$ \\
\hline Gamma glutamyltransferase & $\mathrm{WTE}<\mathrm{NG}^{* * * *}$ & $2008<2010<2009^{* * * *}$ \\
\hline Amylase & $\mathrm{WTE}<\mathrm{NG}^{* * * *}$ & n.s. \\
\hline Glucose & $\mathrm{WTE}<\mathrm{NG}^{* * * *}$ & $2010<2009<2008^{*}$ \\
\hline \multicolumn{3}{|l|}{ Kruskall-Wallis } \\
\hline Protein:creatinine & n.s. & $2008<2009<2010^{\text {***** }}$ \\
\hline Alanine aminotransferase & n.s. & n.s. \\
\hline Total protein & n.s. & n.s. \\
\hline Urea & WTE $<N G^{* * * *}$ & $2010<2009<2008^{\text {tr. }}$ \\
\hline Bile acids & WTE $<\mathrm{NG}^{* *}$ & $2010<2008<2009^{* * * *}$ \\
\hline Inorganic phosphate & NG $<$ WTE $^{*}$ & $2009<2008<2010^{\text {tr. }}$ \\
\hline Calcium & $\mathrm{NG}<\mathrm{WTE}^{* * *}$ & n.s. \\
\hline Magnesium & n.s. & n.s. \\
\hline Sodium & $\mathrm{WTE}<\mathrm{NG} * * * *$ & $2009<2008<2010^{* * * *}$ \\
\hline Potassium & $\mathrm{NG}<\mathrm{WTE}^{* * * *}$ & n.s. \\
\hline
\end{tabular}

n.s.: not significant.

tr.: non-significant trend $(0.05 \leq p<0.10)$

$$
\begin{aligned}
& * p<0.05 \\
& * * p<0.01 \\
& * * * p<0.001
\end{aligned}
$$

significantly correlated (all $p<0.05 ; r=0.21-0.78$ ). OHC concentrations in 2008 and 2009 generally increased in the order golden eagles $<$ goshawks $<$ white-tailed eagles. In 2010, golden eagles had higher concentrations than goshawks. The most dominating PCB congeners were the higher chlorinated CB 138, 153 and 180, while for PBDEs it was BDE 47, 99 and 100. Oxychlordane and trans-nonachlor were the chlordanes found in highest concentrations, while PFOS was the most dominant PFC. As not all OHCs were available from all individuals, only $\sum \mathrm{PCB}, \mathrm{HCB}, p, p^{\prime}-\mathrm{DDE}$, $\sum \mathrm{CHL}$ and $\sum \mathrm{PFC}$ were used in the following data handling.

\subsection{Annual variations}

Significant differences among years were found for eight BCCPs (all $p<0.05$; Tables 1 and 3). Concentrations of blood plasma protein:creatinine ratios, uric acid and sodium were highest in 2010 (all $p<0.05$; Table 3 ) while concentrations of 
fructosamine, bile acids and gamma glutamyltransferase were highest in 2009 (all $p<0.05$; Table 3 ). The concentrations of creatinine and glucose were highest in 2008 (both $p<0.05$; Table 3). Such influences from seasonal and annual variations are not uncommon to find when studying wildlife (Letcher et al., 2010; Sonne, 2010; Sonne et al., In press). The increased blood protein and uric acid concentrations in 2010 could indicate high muscle metabolism and growth, high protein diet or even dehydration (Ettinger and Feldman, 1995; Thrall et al., 2006; Waikar and Bonventre, 2008). The underlying reasons for this are unknown, but could be ascribed to the fact that the three breeding seasons varied with respect to climatic conditions with e.g., one very harsh winter (2009-2010) where birds might have been forced to find new feeding grounds/items (Cramp and Simmons, 1980). Biological factors such as age can be excluded since all specimens were young hatchlings of approximately same age (Braun, 2003; Harr, 2002; Richards and Proszkowiec-Weglarz, 2007; Schulz et al., 2000; Van Loveren et al., 2001).

\subsection{Patterns detected by PCAs}

The PCA resulted in five components with eigen-values above 1 and all of these should therefore be considered (Kaiser's rule; Joliffe, 2002). However, for simplicity, only the first two components were included and these explained ca. $40 \%$ of the total variation in the BCCP data (Fig. 2). Fig. 2 shows the biplot of the first two components with the black arrows representing the correlations of each of the BCCPs with the two first dimensions. It is seen that fructosamine, creatinine, cholesterol and potassium are grouped, as are urea, bile acid and glucose. ALAT and uric acid are also grouped while albumin, total protein, inorganic phosphate and calcium form groups as do bilirubin, ALKP, magnesium and sodium. Fig. 2 also show clear inter-specific differences that

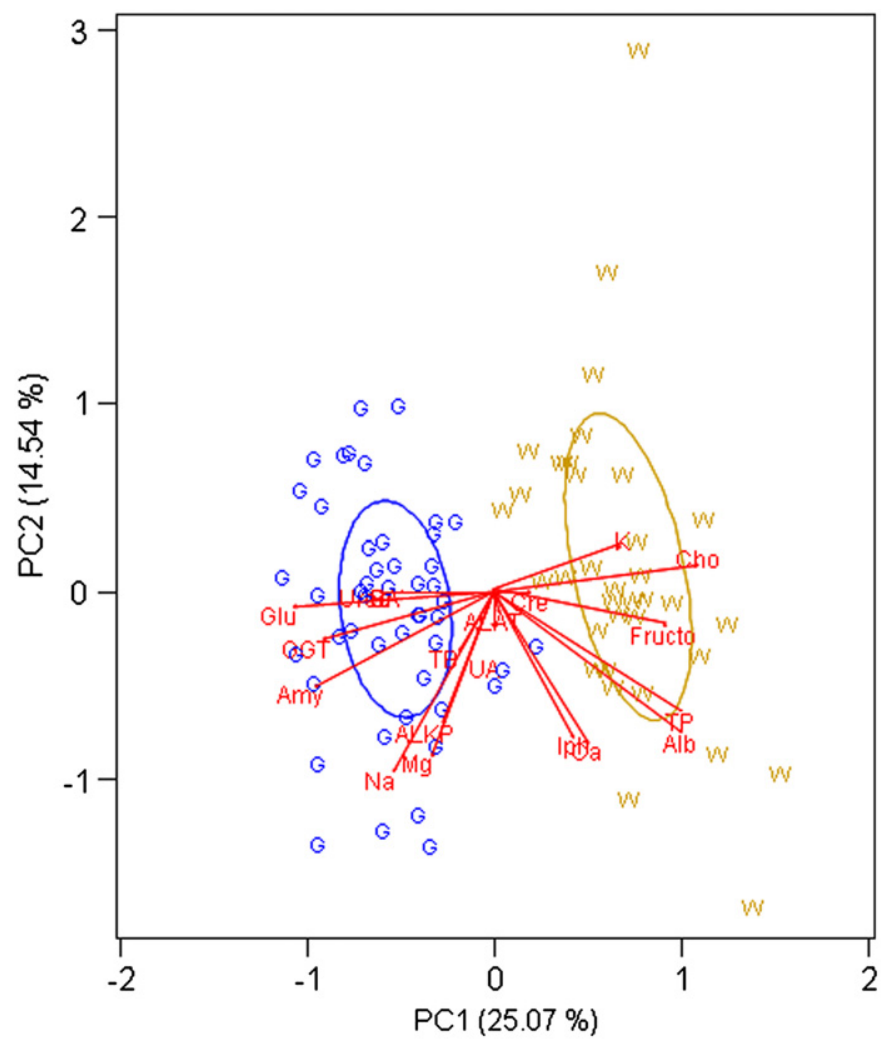

Fig. 2. Biplot of the PCA on BCCP concentrations in white-tailed eagle (W) and northern goshawk $(G)$ nestlings. The eclipses are 95\% confidence limits. See materials and methods for abbreviations. are in agreement with Table 3. The goshawks clearly grouped with gamma glutamyltransferase, bile acid, urea, uric acid, glucose, amylase, sodium, magnesium, alkaline phosphatase, alanine aminotransferase and total bilirubin. The white-tailed eagles are clearly grouped with inorganic phosphate, calcium, albumin, total protein, fructosamine, creatinine, cholesterol and potassium. The PCA was performed on BCCPs scaled to unit variance so it is the pattern rather than the concentration levels that affect the PCA plot. Additional statistical analyses showed that the 95\% eclipse confidence interval of the centroids of all three years overlaps. However, 2010 was to some degree separated from the two other years.

\subsection{Relationships between OHCs and BCCPS}

Since we found significant inter-specific differences for a number of BCCPs, all OHC vs. BCCP correlation analyses were performed separately for each species (Table 4). 20 significant $(p<0.05)$ and 19 non-significant trend $(0.05 \leq p<0.10)$ correlations were found between OHCs and BCCPs across species. In two cases (ALAT vs. $\mathrm{HCB}$ and $\sum \mathrm{CHL}$ ) we found similarities between white-tailed and golden eagles. Of the 20 significant correlations 17 were found in white-tailed eagles and goshawks while only three were found in the lower contaminated golden eagles. Similarly, 17 of the 19 nonsignificant trends were found in white-tailed eagles and goshawks. In the following sections mainly the significant results are discussed and we recognise that the golden eagle sample size may limit some of the interpretations for this species. Avian biochemistry is highly species-specific and reference ranges were not available (Harr, 2002; Schulz et al., 2000; Thrall et al., 2006). Since only little is known about the relationship between BCCPs and OHC exposure in birds we have also included information from mammals in our discussion.

Of the three liver enzymes, ALKP was positively correlated to $\sum$ CHLs in goshawks and ALAT was positively correlated to $\sum$ PCBs, HCB, $\sum$ CHLs and $\sum$ PBDEs in white-tailed eagles and to $\mathrm{HCB}$ and $\sum$ CHLs in golden eagles (Table 4). In white-tailed eagles, however, a negative correlation was found to $\sum$ PFCs. Previous studies of e.g., canvasback ducks (Aythya valisineria) and blackcrowned night heron (Nycticorax nycticorax), laboratory rats and humans have shown that ALAT and ALKP plasma levels increase with exposure to various groups of organochlorines and PBDEs (Alonso et al., 2010; Champoux et al., 2002; Dieter, 1974, 1975; Dieter et al., 1976, 1977; Dieter and Wiemeyer, 1978; Fischbein, 1985; Hayes et al., 1984; Kutlu et al., 2007). These perturbations have shown to be a function of species, exposure route, duration and compound (Arnold et al., 1993; Chu et al., 1994; Stout et al., 2010). Our findings indicate that OHC exposure may have an impact on hepatocyte integrity and function. However, increasing blood plasma concentrations of liver enzymes may also be a result of e.g., hypoxia, inflammation, diet, infection, neoplasia, trauma, metabolic abnormalities (storage diseases), endocrine diseases and/or hepatocyte regeneration (Ettinger and Feldman, 1995; Thrall et al., 2006). Previous studies have shown that PFOS and PFOA increase blood plasma concentrations of ALAT (Hoff et al., 2005; Yahia et al., 2010). This is not in accordance with our findings in white-tailed eagles, indicating that the relationship between BCCPs and OHCs are not always obvious and that studies like the present are not designed to pinpoint cause-and-effect relationships.

Positive correlations were found between cholesterol and all OHCs except $p, p^{\prime}$-DDE in goshawks (Table 4). Also albumin was positively correlated to all $\mathrm{OHC}$ groups except $\sum$ PBDEs across species. Total protein was also positively correlated to HCB in white-tailed eagles and to $p, p^{\prime}$-DDE in goshawks. Regarding total bilirubin, an erythrocyte metabolism waste product, it was negatively correlated to $\sum$ PCBs and positive to $\sum$ PBDEs in golden eagles. Studies of gulls in the Great Lakes showed decreased 
Table 4

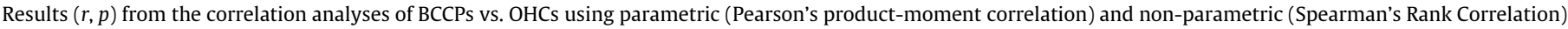
tests. GE: golden eagle, WTE: white-tailed eagle, NG: northern goshawk.

\begin{tabular}{|c|c|c|c|c|c|c|}
\hline BCCPs & $\sum$ PCBs & HCB & $p, p^{\prime}-D D E$ & $\sum$ CHLs & $\sum$ PBDEs & $\sum$ PFCs \\
\hline \multicolumn{7}{|c|}{ Pearson's product-moment correlation } \\
\hline Alkaline phosphatase & WTE: $-0.33^{\text {tr. }}$ & n.s. & n.s. & NG: $0.42^{*}$ & n.s. & n.s. \\
\hline Albumin & NG: $0.37^{\text {tr. }}$ & WTE: $0.34^{\text {tr. }}$ & NG: $0.35^{\text {tr. }}$ & NG: $0.4^{*}$ & n.s. & GE: $0.75^{*}$ \\
\hline Protein:creatinine & WTE: $-0.43^{*}$ & NG: $0.39^{\text {tr. }}$ & n.s. & n.s. & NG: $0.61^{*}$ & n.s. \\
\hline Uric acid & n.s. & NG: $0.39^{\text {tr. }}$ & n.s. & n.s. & WTE: $0.57^{*}$ & n.s. \\
\hline Uric acid:creatinine & GE: $0.7^{\text {tr. }}$ & NG: $0.45^{*}$ & n.s. & n.s. & NG: $0.6^{*} ;$ GE: $0.95^{* *}$ & n.s. \\
\hline Urea:creatinine & n.s. & NG: $0.53^{*}$ & n.s. & n.s. & NG: $0.74^{* * *}$ & n.s. \\
\hline Cholesterol & NG: $0.39^{\text {tr. }}$ & NG: $0.47^{*}$ & n.s. & NG: $0.36^{\text {tr. }}$ & NG: $0.55^{*}$ & NG: $0.36^{\text {tr. }}$ \\
\hline Fructosamine & n.s. & NG: $0.41^{\text {tr. }}$ & NG: $-0.39^{\text {tr. }}$ & n.s. & NG: $0.46^{\text {tr. }}$ & n.s. \\
\hline Creatinine & WTE: $0.43^{*}$ & n.s. & WTE: $0.32^{\text {tr. }}$ & n.s. & NG: $-0.53^{*}$ & n.s. \\
\hline Total bilirubin & GE: $-0.98^{* * * *}$ & n.s. & n.s. & n.s. & GE: $0.84^{*}$ & NG: $0.38^{\text {tr. }}$ \\
\hline \multicolumn{7}{|l|}{ Spearman's rank correlation } \\
\hline Alanine aminotransferase & WTE: $0.38^{*}$ & WTE: $0.51^{* *} ;$ GE: $0.92^{* *}$ & n.s. & WTE: $0.66^{*}$ & WTE: $0.48^{* * *} ;$ GE: $0.76^{*}$ & WTE: $-0.39 *$ \\
\hline Gamma glutamyltransferase & n.s. & n.s. & n.s. & n.s. & n.s. & n.s. \\
\hline Amylase & n.s. & n.s. & n.s. & n.s. & n.s. & n.s. \\
\hline Total protein & n.s. & WTE: $0.37^{*}$ & NG: $0.42^{*}$ & n.s. & n.s. & n.s. \\
\hline Urea & WTE: $0.37^{*}$ & n.s. & n.s. & n.s. & GE: $-0.64^{\text {tr. }}$ & n.s. \\
\hline Bile acids & n.s. & n.s. & n.s. & n.s. & n.s. & n.s. \\
\hline Glucose & NG: $-0.41^{*}$ & n.s. & n.s. & n.s. & NG: $-0.35^{\text {tr. }}$ & WTE: $0.36^{\text {tr. }}$ \\
\hline Inorganic phosphate & NG: $0.4^{*}$ & n.s. & NG: $0.47^{*}$ & n.s. & n.s. & n.s. \\
\hline Calcium & n.s. & n.s. & n.s. & NG: $0.52^{*}$ & n.s. & GE: $0.93^{* * *}$ \\
\hline Magnesium & n.s. & NG: $-0.37^{\text {tr. }}$ & n.s. & n.s. & n.s. & n.s. \\
\hline Sodium & n.s. & n.s. & n.s. & n.s. & WTE: $0.39^{*}$ & n.s. \\
\hline Potassium & n.s. & n.s. & NG: $-0.38^{\operatorname{tr}}$ & n.s. & n.s. & n.s. \\
\hline
\end{tabular}

${ }^{*} p<0.05$.

*** $p<0.01$.

$* * * * * 0.001$.

plasma concentrations of bilirubin and cholesterol in a highly OHC-contaminated group of gulls when compared to a low contaminated group (Fox et al., 2007). Similar results were found for cholesterol in Great blue herons (Ardea herodias) from The St. Lawrence River (Champoux et al., 2002). Tryphonas et al. (1984) found increased blood concentrations of cholesterol and bilirubin in PCB treated cynomolgus monkeys (Macaca fascicularis). In addition, cholesterol and bilirubin seemed to increase with increasing PCB concentrations in humans (Stehr-Green et al., 1986). Oberg et al. (2010) treated male and female SpragueDawley rats for 28 day (2.5-250 mg per kg body weight per day) with a mixture of PBDEs and found increased blood plasma concentrations of total protein, cholesterol and albumin. van der Ven et al. (2008) also found increased blood concentrations of cholesterol in a study of male Wistar rats fed $0.27-200 \mathrm{mg}$ pentaBDE per kg bw per day.

The protein waste product uric acid and urea was positively correlated to $\sum$ PCBs and $\sum$ PBDEs in white-tailed eagles (Table 4). The muscle break-down product (creatinine) was positively correlated to $\sum \mathrm{PCBs}$ in white-tailed eagles and negative correlated to $\sum$ PBDEs in goshawks. Protein:creatinine, urea:creatinine and uric acid:creatinine ratios (reflecting glomerular filtration rates) were positively correlated to $\sum$ HCB and $\sum$ PBDEs in goshawks while protein:creatinine was negatively correlated to $\sum$ PCBs in white-tailed eagles. In golden eagles, uric acid:creatinine was positively correlated to $\sum$ PBDEs. Total protein, albumin, urea, uric acid, creatinine, uric acid:creatinine, urea:creatinine and protein:creatinine can be viewed as renal parameters. All except protein:creatinine in white-tailed eagles increased significantly with increasing $\mathrm{OHC}$ concentrations across species which indicates lower clearance and filtration rates (glomerular functioning) as a result of OHC exposure. Chu et al. (1994) found a similar urea increase in their study of PCB-exposed female rats. In addition, previous $\mathrm{OHC}$ studies of Arctic species have shown renal histopathological changes that would allow such interpretations (Sonne et al., 2006, 2007, 2008). The increased blood protein and uric acid concentrations could also be influenced by other factors such as muscle metabolism and growth, high protein diet and dehydration (Ettinger and Feldman, 1995; Thrall et al., 2006; Waikar and Bonventre, 2008).

Glucose was negatively correlated to $\sum$ PCBs in goshawks which could indicate endocrine changes since plasma fructosamine was not affected and because birds in general are known to maintain high plasma glucose concentrations (Table 4; Braun and Sweazea, 2008). The endocrine pathways for this could be that PCB reduce the stress-driven maximum corticosterone response and thereby suppress plasma glucose concentrations (Jørgensen et al., 2006; Lacroix and Hontela, 2003).

of the five electrolytes/minerals (inorganic phosphate; calcium; magnesium; sodium; potassium), inorganic phosphate was positively correlated to $\sum$ PCBs and $p, p^{\prime}$-DDE in goshawks (Table 4). Calcium was positively correlated to $\sum$ PBDEs and $\sum$ PFCs in goshawks and golden eagles, respectively, while sodium was positively correlated to $\sum$ CHLs in white-tailed eagles. Changes in these more overall and broader biochemical endpoints are hard to interpret but may indicate an increase in bone resorption as seen in e.g., PCB exposed laboratory rats (Yilmaz et al., 2006). The potential pathways modulated in this are parathyroid hormone and calcitonin activity in intestines, bone tissue (osteoclasts) and kidneys. When considering sodium, the increase with $\sum$ CHLs in white-tailed eagles could be linked to renal function while dehydration is also known to affect sodium fluctuations (Ettinger and Feldman, 1995; Thrall et al., 2006; Waikar and Bonventre, 2008).

\subsection{Health considerations}

Despite the statistical relationships between OHCs and BCCPs, it is unknown if the contaminant concentrations are of concern for the general health of the three species of Norwegian raptor nestlings. Compared with other contaminated raptor species the present raptor concentrations are moderate. For example, 
Californian and Canadian bald eagle (Haliaeetus leucocephalus) nestlings had plasma DDE concentrations that were slightly higher than in the present study while the PCB concentrations were lower. In those bald eagles, $p, p^{\prime}$-DDE and $\sum$ PCB were negatively correlated to blood plasma thyroid T3 and T4 hormone concentrations indicating subclinical endocrine-disrupting health effects (Cesh et al., 2010; Sonne, 2010). However, when comparing the plasma concentrations with egg concentrations using conversion factors, the concentrations in the Norwegian raptor nestlings were below toxic threshold levels for fertility in e.g., adult bald eagles and ospreys (Pandion haliaetus) (Elliott and Harris, 2002; García-Fernández et al., 2008; Strause et al., 2007). Therefore, population effects from $\mathrm{OHC}$ exposure are not likely to occur in the Norwegian nestlings although the most contaminated nestlings could suffer from reduced fitness.

\section{Conclusions}

The present study shows that there are large species differences in blood clinical-chemical parameters between Norwegian raptor nestlings and that certain years may deviate significantly in patterns and concentrations. The statistical relationships between OHCs and BCCPs indicate that biochemical pathways could be influenced while it is uncertain if such changes have any health effects. The OHC concentrations were below concentrations for reproductive toxicity in adults of other raptor species but similar to those of concern for endocrine disruption of thyroid hormones in e.g., bald eagles.

\section{Acknowledgements}

The Norwegian Research Council is acknowledged for funding RAPTOR while The Funds for Scientific Research Flanders and the University of Antwerp are acknowledged for funding Dr. VLB Jaspers, Dr. A Covaci, Dr. M Eens and I Eulaers. Laboratory technicians at the Department of Small Animal Clinical Sciences (University of Copenhagen, Denmark) and at the Norwegian Institute for Air Research are acknowledged for conducting the $\mathrm{BCCP}$ and $\mathrm{OHC}$ analyses, respectively.

\section{References}

Alonso, V., Linares, V., Bellés, M., Albina, M.L., Pujol, A., Domingo, J.L., Sánchez, D.J., 2010. Effects of BDE-99 on hormone homeostasis and biochemical parameters in adult male rats. Food Chem. Toxicol. 48, 2206-2211.

AMAP, 1998. Arctic pollution 1998; Arctic Monitoring and Assessment Programme, Oslo, Norway.

AMAP, 2004. Persistent Organic Pollutants in the Arctic. Arctic pollution 2002. Arctic Monitoring and Assessment Programme, Oslo, Norway.

Arnold, D.L., Bryce, F., Karpinski, K., Mes, J., Fernie, S., Tryphonas, H., Truelove, J., McGuire, P.F., Burns, D., Tanner, J.R., Stapley, R., Zawidzka, Z.Z., Basford, D., 1993. Toxicological consequences of Aroclor 1254 ingestion by female rhesus (Macaca mulatta) monkeys. Part 1B. Prebreeding phase: clinical and analytical laboratory findings. Food Chem. Toxicol. 11, 811-824.

Braun, E.J., 2003. Regulation of renal and lower gastrointestinal function: role in fluid and electrolyte balance. Comp. Biochem. Physiol. A: Mol. Integr. Physiol. 136, 499-505

Braun, E.J., Sweazea, K.L., 2008. Glucose regulation in birds. Comp. Biochem. Physiol. B: Biochem. Mol. Biol. 151, 1-9.

Bustnes, J.O., Tveraa, T., Fauchald, P., Helberg, M., Skaare, J.U., 2008. The potential impact of environmental variation on the concentrations and ecological effects of pollutants in a marine avian top predator. Environ. Int. 34, 193-201.

Cesh, L.S., Elliott, K.H., Quade, S., McKinney, M.A., Maisoneuve, F., Garcelon, D.K. Sandau, C.D., Letcher, R.J., Williams, T.D., Elliott, J.E., 2010. Polyhalogenated aromatic hydrocarbons and metabolites: relation to circulating thyroid hormone and retinol in nestling bald eagles (Haliaeetus leucocephalus). Environ. Toxicol. Chem. 29, 1301-1310.

Champoux, L., Rodrigue, J., Desgranges, J.L., Trudeau, S., Hontel, A., Boily, M., Spear, P., 2002. Assessment of contamination and biomarker responses in two species of herons on the St. Lawrence River. Environ. Monit. Assess. 79, 193-215.
Chrousos, G.P., Gold, P.W., 1992. The concepts of stress and stress system disorders. Overview of physical and behavioural homeostasis. JAMA 267, 1244-1252.

Chu, I., Villeneuve, D.C., Yagminas, A., Lecavalier, P., Poon, R., Feeley, M., Kennedy, S.W. Seegal, R.F., Hakansson, H., Ahlborg, U.G., Valli, V.E., 1994. Subchronic toxicity of 3,3',4,4',5-pentachlorobiphenyl in the rat. 1. Clinical, biochemical, hamatological and histopathological changes. Fundam. Appl. Toxicol. 22, 457-468.

Cramp, S., Simmons, K.E.L., 1980. In: Cramp, S., Simmonds, K.E.L. (Eds.), The Birds of the Western Palearctic, vol. III. University Press, UK, Oxford, pp. 695.

de le Court, C., Aguilera, E., Recio, F., 1995. Plasma chemistry values of free-living white spoonbills (Platalea leucorodia). Comp. Biochem. Physiol. 112, 137-141.

Dieter, M.P., Perry, M.C., Mulhern, B.M., 1976. Lead and PCB's in canvasback ducks: relationship between enzyme levels and residues in blood. Arch. Environ. Contam. Toxicol. 5, 1-13.

Dieter, M.P., Perry, M.C., Mulhern, B.M., 1977. Lead and PCBs in canvasback ducks relationship between enzyme levels and residues in blood. Arch. Environ. Contam. Toxicol. 5, 1-13.

Dieter, M.P., Wiemeyer, S.N., 1978. Six different plasma enzymes in bald eagles (Haliaeetus leucocephalis) and their usefulness in pathological diagnosis. Comp. Biochem. Physiol. 61, 153-155.

Dieter, M.P., 1974. Plasma enzyme activities in Coturnix quail fed graded doses of DDE, polychlorinated biphenyl, malathion and mercuric chloride. Toxicol. Appl. Pharmacol. 27, 86-98.

Dieter, M.P., 1975. Further studies of the use of enzyme profiles to monitor residue accumulation in wildlife: plasma enzymes in starlings fed graded concentrations of Morsodren, DDE, Aroclor 1254, and malathion. Arch. Environ. Contam. Toxicol. 3, 142-150.

Elliott, J.E., Harris, M.L., 2002. An ecotoxicological assessment of chlorinated hydrocarbon effects on bald eagle populations. Rev. Toxicol. 4, 1-60.

Ettinger, S.J., Feldman, E.C., 1995. In: Ettinger, S.J., Feldman, E.C. (Eds.), Textbook of Veterinary Internal Medicine. W.B. Saunders, Philadelphia, USA

Eulaers, I., Covaci, A., Herzke, D., Eens, M., Sonne, C., Moum, T., Schnug, L., Hanssen, S.A., Johnsen, T.V., Bustnes, J.O., Jaspers, V.L.B., 2011. A first evaluation of the usefulness of feathers of nestling predatory birds for non-destructive biomonitoring of persistent organic pollutants. Environ. Int. (37), 622-630.

Ferrer, M., Dobado-Berrios, P., 1998. Factors affecting plasma chemistry values of the Spanish Imperial Eagle Aquila adalberti. Comp. Biochem. Physiol. A 120, 209-217.

Fischbein, A., 1985. Liver function tests in workers with occupational exposure to polychlorinated biphenyls (PCBs): comparison with Yusho and Yu-cheng. Environ. Health Perspect. 60, 145-150.

García-Fernández, A.J., Calvo, J.F., Martínez-López, E., María-Mojica, P., Martínez J.E., 2008. Raptor ecotoxicology in Spain: a review on persistent environmental contaminants. Ambio 37, 432-439.

Fox, G.A., Jeffrey, D.A., Williams, K.S., Kennedy, S.W., Grasman, K.A., 2007. Health of Herring gulls (Larus argentatus) in relation to breeding location in the early 1990 s. I. biochemical measures. J. Toxicol. Environ. Health Part A 70, 1443-1470.

Gjershaug, J.O., Kålås, J.A., Nygård, T., Herzke, D., Folkestad, A.O., 2008. Monitoring of raptors and their contamination levels in Norway. Ambio 37, 420-424

Götsch, A., Mariussen, E., von der Recke, R., Herzke, D., Berger, U., Vetter., W., 2004 Analytical strategies for successful enantioselective separation of atropisomeric polybrominated biphenyls 132 and 149 in environmental samples. J. Chromatogr. A 1063, 193-199.

Harr, K.E., 2002. Clinical chemistry of companion avian species: a review. Vet. Clin. Pathol. 31, 140-151.

Hayes, M.A., Roberts, E., Roomi, M.W., Safe, S.H., Farber, E., Cameron, R.G., 1984 Comparative influences of different PB-type and 3-MC-type polychlorinated biphenyl-induced phenotypes on cytocidal hepatotoxicity of bromobenzene and acetaminophen. Toxicol. Appl. Pharmacol. 76, 118-127.

Helberg, M., Bustnes, J.O., Erikstad, K.E., Kristiansen, K.O., Skaare, J.U., 2005. Relationships between reproductive performance and organochlorine pollutants in greatblack backed gulls (Larus marinus). Environ. Pollut. 134, 475-483.

Herzke, D., Kallenborn, R., Nygård, T., 2002. Organochlorines in egg samples from Norwegian birds of prey: congener-, isomer- and enantiomer specific considerations. Sci. Total Environ. 291, 59-71.

Herzke, D., Berger, U., Kallenborn, R., Nygård, T., Vetter, W., 2005. Brominated flame retardants and other organobromines in Norwegian predatory bird eggs. Chemosphere 61, 441-449.

Hoff, P.T., Van de Vijver, K., Dauwe, T., Covaci, A., Maervoet, J., Eens, M., Blust, R., De Coen, W., 2005. Evaluation of biochemical effects related to perfluorooctane sulfonic acid exposure in organohalogen-contaminated great tit (Parus major) and blue tit (Parus caeruleus) nestlings. Chemosphere 61, 1558-1569.

Johnson, E.O., Kamilaris, T.C., Chrousos, G.P., Gold, P.W., 1992. Mechanisms of stress: a dynamic overview of hormonal and behavioral homeostasis. Neurosci. Biobehav. Rev. 16, 115-130.

Joliffe, I.T., 2002. Principal Component Analysis, 2nd edn. Springer 2002, ISBN 0387954422, 9780387954424, 487..

Jørgensen, E.H., Vijayan, M.M., Killie, J.E., Aluru, A., Aas-Hansen, N., Maule, A., Ø. 2006. Toxicokinetics and effects of PCBs in Arctic fish: a review of studies on Arctic charr. J. Toxicol. Environ. Health Part A 69, 37-52.

Julshamn, K., Lundebye, A.K., Heggstad, K., Berntssen, M.H., Boe, B., 2004 Norwegian monitoring programme on the inorganic and organic contaminants in fish caught in the Barents Sea, Norwegian Sea and North Sea, 1994-2001. Food Addit. Contam. 21, 365-376.

Kutlu, S., Colakoglu, N., Halifeoglu, I., Sandal, S., Seyran, A.D., Aydin, M., Yilmaz, B., 2007. Comparative evaluation of hepatotoxic and nephrotoxic effects of aroclors 1221 and 1254 in female rats. Cell Biochem. Funct. 25, 167-172. 
Lacroix, M., Hontela, A., 2003. The organochlorine p,p'-DDD disrupts the adrenal steroidogenicsignaling pathway in rainbow trout (Oncorhynchus mykiss). Toxicol. Appl. Pharmacol. 190, 197-205.

Letcher, R.J., Bustnes, J.O., Dietz, R., Jenssen, B.M., Jørgensen, E.H., Sonne, C., Verreault, J., Vijayan, M.M., Gabrielsen, G.W., 2010. Effects assessment of persistent organohalogen contaminants in Arctic wildlife and fish. Sci. Total Environ. 408, 2995-3043.

Oberg, M., Westerholm, E., Fattore, E., Stern, N., Hanberg, A., Haglund, P., Wiberg K., Bergendorff, A., Hakansson, H., 2010. Toxicity of Bromkal 70-5DE, technical mixture of polybrominated diphenyl ethers, following $28 \mathrm{~d}$ of oral exposure in rats and impact of analysed impurities. Chemosphere 80 137-143.

Perneger, T.V., 1998. What's wrong with Bonferroni adjustments. BMJ 316 1236-1238.

R Development Core Team., 2011. R: A language and environment for statistical computing. R Foundation for Statistical Computing, Vienna, Austria. ISBN 3-900051-07-0, URL http://www.R-project.org/.

Richards, M.P., Proszkowiec-Weglarz, M., 2007. Mechanisms regulating feed intake, energy expenditure, and body weight in poultry. Poult. Sci. 86, 1478-1490.

Schulz, J.H., Bermudez, A.J., Tomlinson, J.L., Firman, J.D., He, Z., 2000. Blood plasma chemistries from wild mourning doves held in captivity. J. Wildlife Dis. 36 , 541-545.

Sharit., J., Salvendy., G., 1982. Occupational stress: review and reappraisal. Hum. Factor Ergon. Manuf. Serv. Ind. 24, 129-162.

Sonne, C., 2010. Health effects from long-range transported contaminants in Arctic top predators: an integrated review based on studies of polar bears and relevant model species. Environ. Int. 36, 461-491.

Sonne, C., Dietz, R., Leifsson, P.S., Born, E.W., Kirkegaard, M., Letcher, R.J., Muir D.C.G., Rigét, F.F., Hyldstrup, L., 2006. Are organohalogen contaminants a cofactor in the development of renal lesions in East Greenland polar bears (Ursus maritimus)? Environ. Toxicol. Chem. 25, 1551-1557.

Sonne, C., Leifsson, P.S., Dietz, R., Kirkegaard, M., Møller, P., Jensen, A.L., Letcher R.J., Shahmiri, S., 2007. Renal lesions in Greenland sledge dogs (Canis familiaris) exposed to a natural dietary cocktail of persistent organic pollutants. Toxicol. Environ. Chem. 89, 563-576.

Sonne, C., Dietz, R., Kirkegaard, M., Letcher, R.J., Shahmiri, S., Andersen, S., Møller, P., Olsen, A.K., Jensen, A.L., 2008. Effects of organohalogen pollutants on haematological and urine clinical-chemical parameters in greenland sledge dogs (Canis familiaris). Ecotoxicol. Environ. Saf. 69, 381-390.

Sonne, C., Bustnes, J.O., Herzke, D., Jaspers, V.L.B., Covaci, A., Halley, D.J., Minagawa, M., Moum, T., Eulaers, I., Eens, M., Ims, R.A., Hanssen, S.A., Erikstad, K.E., Johnsen, T., Schnug, L., Jensen, A.L., 2010. Relationships between organohalogen contaminants and blood plasma clinical-chemical parameters in chicks of three raptor species from Northern Norway. Ecotoxicol. Environ. Saf. 73, 7-17.
Sonne, C., Dietz, R., Letcher, R.J., Bechshøft, T.Ø., Rigét, F.F., Muir, D.C.G., Leifsson, P.S., Hyldstrup, L., In press. Biomonitoring polar bear health in Greenland: A messenger for global pollution and climate warming. Acta. Vet. Scan.

Stehr-Green, P.A., Welty, E., Steele, G., Steinberg, K., 1986. Evaluation of potential health effects associated with serum polychlorinated biphenyl levels. Environ. Health Perspect. 70, 255-259.

Stout, J.D., Brinker, D.F., Driscoll, C.P., Davison, S., Murphy, L.A., 2010. Serum biochemistry values, plasma mineral levels, and whole blood heavy metal measurements in wild Northern Goshawks (Accipiter gentilis). J. Zoo Wild. Med. 41, 649-655.

Strause, K.D., Zwiernik, M.J., Im., S...H., Newsted., J.L., Kay, D.P., Bradley, P.W. Blankenship, A.L., Williams, L.L., Giesy, J.P., 2007. Plasma to egg conversion factor for evaluating polychlorinated biphenyl and DDT exposures in great horned owls and bald eagles. Environ. Toxicol. Chem. 26, 1399-1409.

Thrall, M.A., Baker, D.C., Campbell, T.W., DeNicola, D.B., Fettman, M.J., Lassen, E.D., Rebar, A., Weiser, A., 2006. Veterinary Hematology and Clinical Chemistry: Text and Clinical Case Presentations Set. Blackwell Publishing, Iowa, USA.

Tryphonas, L., Truelove, J., Zawidzka, Z., Wong, J., Mes, J., Charbonneau, S., Grant, D.L., Campbell, J.S., 1984. Polychlorinated biphenyl (PCB) toxicity in adult cynomolgus monkeys (M. fascicularis): a pilot study. Toxicol. Pathol. 12, 10-25.

van der Ven, L.T.M., van de Kuil, T., Verhoef, A., Leonards, P.E.G., Slob, W., Canton, R.F., Germer, S., Hamers, T., Visser, T.J., Litens, S., Hakansson, H., Fery, Y., Schrenk, van den Berg, D., Piersma, A.H., Vos, J.G., 2008. A 28-day oral dose toxicity study enhanced to detect endocrine effects of a purified technical pentabromodiphenyl ether (pentaBDE) mixture in Wistar rats. Toxicology 245, 109-122.

Van Loveren, H., van Amsterdam, J.G., Vandebriel, R.J., Kimman, T.G., Rumke, H.C., Steerenberg, P.S., Vos, J.G., 2001. Vaccine-induced antibody responses as parameters of the influence of endogenous and environmental factors. Environ. Health Perspect. 109, 757-764.

vanWyk, E., van der Bank, H., Verdoorn, G.H., 1998. Dynamics of haematology and blood biochemistry in free-living African whitebacked vulture (Pseudogyps africanus) nestlings. Comp. Biochem. Physiol. A 120, 495-508.

Waikar, S.S., Bonventre, J.V., 2008. Biomarkers for the diagnosis of acute kidney injury. Nephron Clin. Pract. 109, 192-197.

Yahia, D., El-Nasser, M.A., Abedel-Latif, M., Tsukuba, C., Yoshida, M., Sato, I., Tsuda, S., 2010. Effects of perfluorooctanoic acid (PFOA) exposure to pregnant mice on reproduction. J. Toxicol. Sci. 35, 527-533.

Yilmaz, B., Seyran, A.D., Sandal, S., Aydin, M., Colakoglu, N., Kocer, M., Carpenter, D.O., 2006. Modulatory effects of Aroclors 1221 and 1254 on bone turnover and vertebral histology in intact and ovariectomized rats. Toxicol. Lett. 166, 276-284.

Zar, J.H., 1984. Biostatistical Analysis, 2nd edn. Prentice-Hall, Inc, New Jersey, USA. 